\title{
Artificial Modification of Bacterial Surface with Cell-Wall Engineering
}

\author{
細胞壁生合成を利用したバクテリア人工機能化
}

\author{
Sadamoto, Reiko \\ Shionogi Laboratory of Biomolecular Chemistry, Division of Biological Sciences, Graduate School of Science, \\ Frontier Research Center for Post-Genomic Science and Technology, \\ Hokkaido University, Kita 21 Nishi 11, Kita-ku, Sapporo 001-0021, Japan \\ FAX: 81-11-706-9044, E-mail: reikosd@glyco.sci.hokudai.ac.jp
}

Key Words: bacterial cell wall, surface modification, muramic acid

\begin{abstract}
This article deals with cell-surface engineering using bacterial cell wall aiming for the development of new mucosal vaccines. We developed a method for artificial modification of live bacteria. As precursors to be incorporated into bacterial cell wall, muramic acid derivatives with ketone moiety were synthesized. When the synthesized precursor was added to growth media, it was transferred through biosynthetic pathway of the cell wall and the ketone group was displayed on the surface of bacteria. Examples of bacterial surface modifications by this method are described.
\end{abstract}

要 約

乳酸菌などの腸内細菌の細胞壁を利用した新しい粘膜り クチン製造を目指したバクテリア表層工学について述べる。 生きたままのバクテリアの表面を人工的に機能化する手法を 開発した。バクテリア細胞壁の前駆体として、ケトン基なと をつけたムラミン酸誘導体を合成した。乳酸菌の培養液にこ れを添加して培養すると、細胞壁の生合成経路にとりこまれ、 バクテリア表面へケトン基が提示された。これを利用して、 バクテリアの表面機能性を変化させた例を紹介する。

A. イントロダクション

A-1. ケミカルバイオロジー的アプローチによる細胞表層工学 遺伝子組み換えなどの手法を使って、微生物(ファージ・ 酵母・バクテリアなど) の表面に目的タンパク質を表層タンパ クとの融合タンパク質として提示させる研究は以前から精力 的に進められている(1-5)。例えばファージ表層にペプチドラ イブラリーを提示させる手法は、ファージディスプレイ法と して in vitro selection などで一般的に使われる技術となってい る。大腸菌や酵母表層に機能性のタンパク質を提示させるこ とができれば(図 1a)、環境ホルモンや重金属の回収や分解な ども可能な新しいバイオリアクターの創成につながる诃能性 がある。今までは主に遺伝子工学的な手法で機能性タンパク やペプチドを表層に提示させるという手法が中心であったが、 より簡便な方法で提示できる生物化学的な手法も開発されて きた。アジド基を含む非天然のアミノ酸がメチオニンの代わ りにタンパク質に取り込まれるという性質を利用して、大腸 菌の表層改变を行った例も報告されている(6)。しかしこの場 合も表層タンパクを遺伝子工学的にメチオニンリッチに改变 しておく必要がある。

これとは別に、遺伝子組み換えによる発現ではなく、細胞 内の生合成経路に人工前駆体をのせるというケミカルバイオ ロジー的なアプローチによる動物細胞表層上への物質提示 (図 


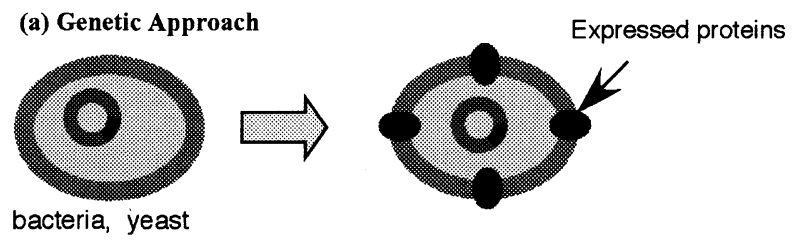

(b) Chemical Approach

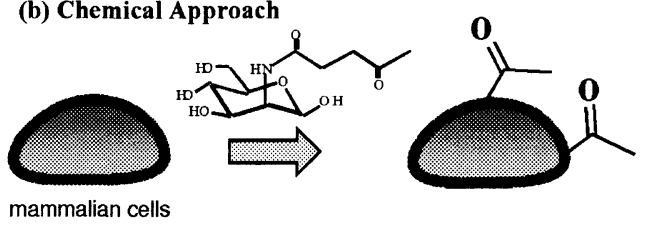

(c) Chemical Engineering of the Bacterial Cell Wall (our method)

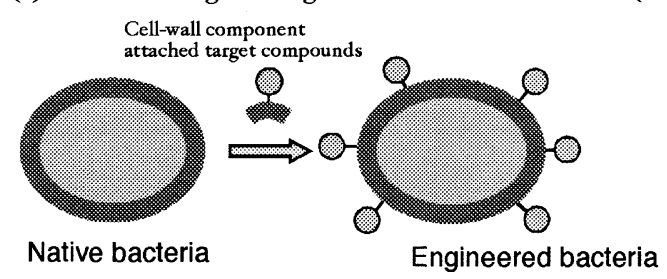

Fig. 1. Genetic and chemical approaches for cell surface display.

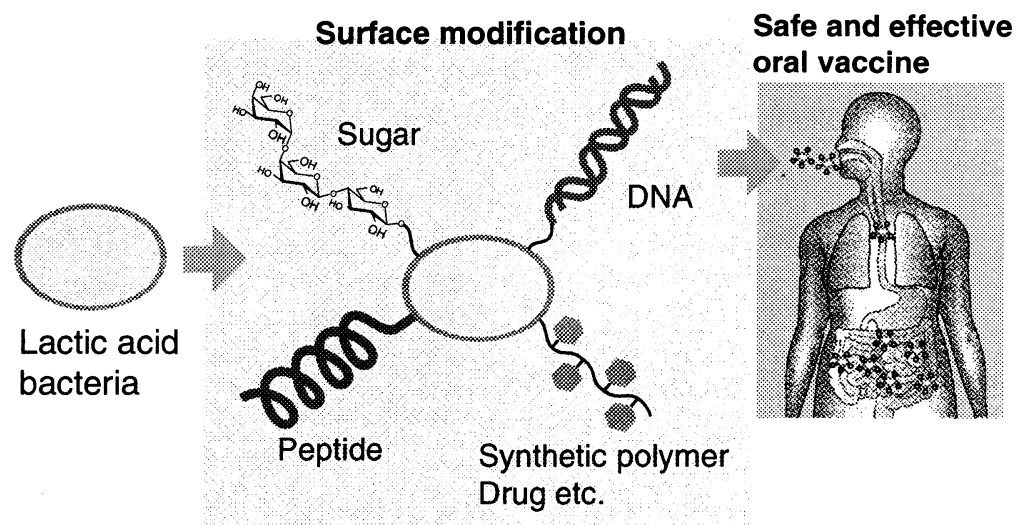

Fig. 2. Bacterial cell-surface display toward safe and effective oral vaccines.

metabolism. By this methodology, reactive groups that can be connected to other chemicals in water, such as ketone, were displayed with sialic acid on the cell surface. It is applicable to the detection of cancer cells which display sialic acid on the surface. They reported recently that they have developed the concept of this method to $O$-linked glycoproteins using GalNAc analog (15).

However, modification of bacterial surface cannot be done by the above method because there are usually no available sialic acid or $O$-glycans on the bacterial surface. We focused on peptidoglycan, a common structural element of bacterial surface as the target of modification that is widely applicable to all bacteria (16-20, Fig.1c). The peptidoglycan consists of polysaccharides of GlcNAc- $\beta(1-4)$ MurNAc repeating unit, in which the polysaccharides are cross-linked
1b)がC. R. Bertozziらによって開拓された (7-14)。彼女らは 細胞表層に存在するシアル酸に着目し、シアル酸の天然の前 駆体である $N$-アセチルマンノサミンではなく、ケトン基を有 する $N$-レブリノイルマンノサミンを細胞に添加するとシアル 酸生合成経路に取り込まれ、ケトン基を有する $\mathrm{N}$-レブリノイ ルノイラミン酸に効率よく変換されることを見いだした。こ の発見により細胞表層のシアル酸を介してケトン基のような 水中でさらなる修飾可能な官能基を提示させることができる。 これらの技術によりシアル酸が多く発現しているガン細胞な どの特異的検出への応用が可能となる。近年、このコンセプ 卜をさらに発展させ、O-グリカンの GalNAc を利用して糖夕 ンパク質にアジド基を提示できる前駆体モノマーなども発表 している (15)。

しかし、Bertozzi らの手法そのものでは我々の目標である バクテリアの表層改変は難しい。シアル酸や $O$-グリカンが 必ずしもバクテリア表層に存在しているわけではないからで 


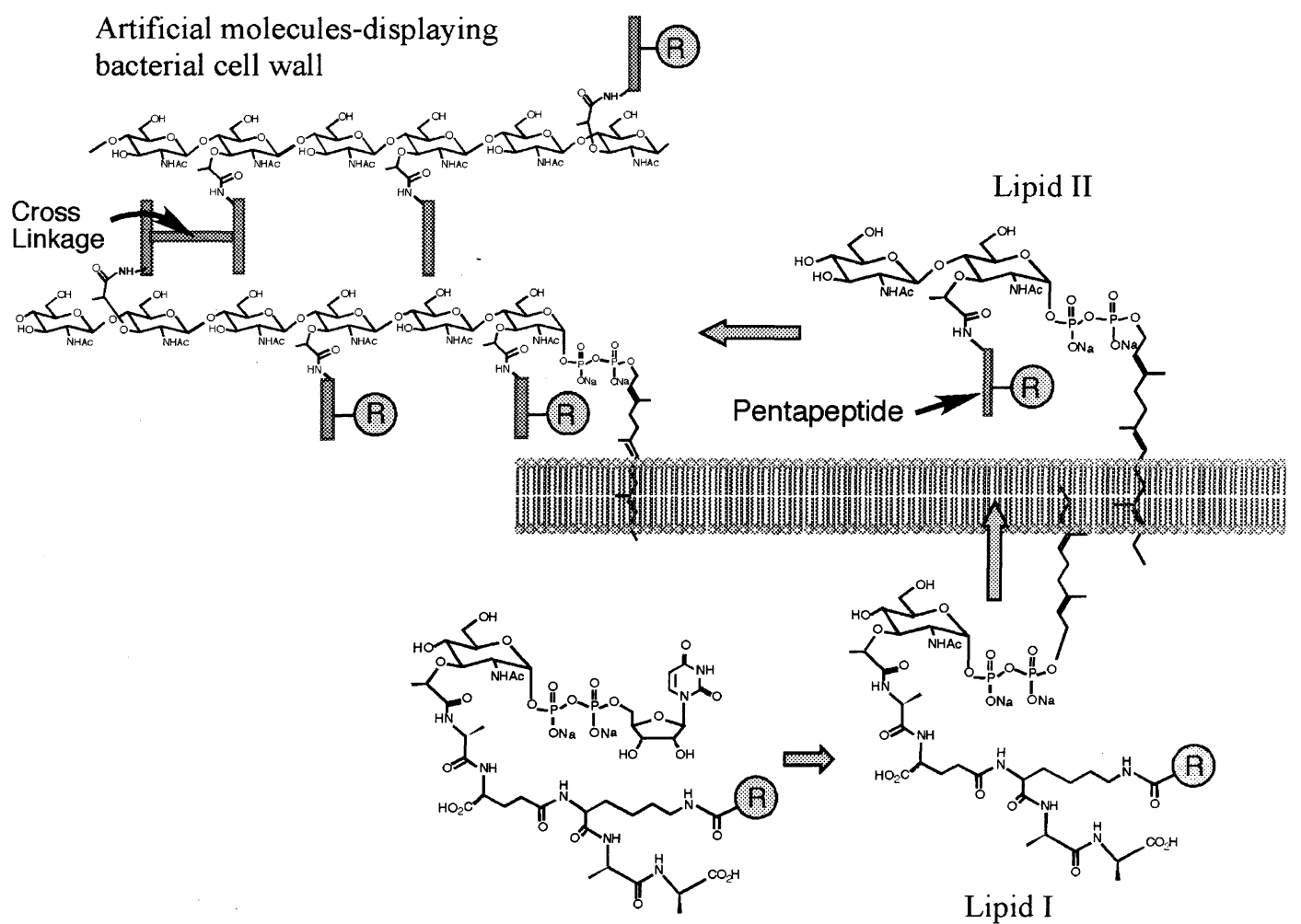

UDP-MurNAc pentapeptide derivatives

II

\section{Artificial cell-wall precursor}

Fig. 3. Bacterial cell wall biosynthesis.

via short peptide chains. Bacterial surface engineering (Fig. 2), such as displaying epitopes, based on this common structure of the cell wall is expected to be applicable to all bacteria. In particular, gram-positive bacteria such as lactic acid bacteria are suitable to be surface-engineered by this method because they have thick layers of the peptidoglycan and do not have outer membrane. Biosynthetic pathways of the bacterial cell wall are shown in Fig. 3. In this article, synthesis of modified precursors and bacterial surface engineering using these precursors are described.

\section{A-2. For Applications to Oral Vaccine Development}

At present, there are two kinds of conventional vaccines, inactivated vaccine and live-attenuated vaccine. Live-attenuated oral vaccine, such as oral polio vaccine, particularly has multiple advantages in stimulating mucosal immune response. However, it may cause the infection itself due to the accidentally recovered pathogenicity.

We expected that effective and safe mucosal-live vaccine as "pseudo live vaccine" is to be made by epitope display on the surface of safe bacteria such as lactic acid bacteria. Live lactic acid bacteria can be delivered to the
ある。そこでバクテリア全般に応用可能なターゲットとして バクテリア細胞壁 (ペプチドグリカン) に着目しこれを利用し た表層修飾法を開発した (16-20、図 1c)。ペプチドグリカンは B1-4 結合した GlcNAc と MurNAc ( $N$-アセチルムラミン酸) の 繰り返し構造を有する多糖で構成されており、それらが短鎖 ペプチドによって架橋している。バクテリア細胞壁の化学構 造はバクテリアの種類によらずほぼ同じであるため、この細 胞壁を抗原などの提示の足場にできればバクテリア一般に適 用可能な応用範囲の広い技術となる (図 2)。特に乳酸菌の上 うなグラム陽性菌は厚い細胞壁で表層が覆われており、提示 に適している。このレビューでは、この経路にある細胞壁前 駆体の誘導体の化学合成䇽よびその細胞壁への取り込みを利 用した新しいバクテリア修飾法について述べる。

\section{A-2. 経ロワクチンへの応用展開}

従来のワクチンは成分としてウイルスや細菌を物理的・化 学的に不活性化した微生物を使うか ( 不活化ワクチン)、ある いは人に対する病原菌が極めて弱くなった病原菌を用いてい る(弱毒生ワクチン)。中でも特に粘膜免疫を誘導できる経口 生ワクチンは、ポリオワクチンに代表されるように効果的で ある。しかしごくまれに、病気を引き起こす能力を失ってい るはずの病原体が、なんらかの理由で病原性を復活させ、ワ クチンを使って防ぐはずの感染症を引き起こしてしまうとい うことが起きる。 
mucosal immune system effectively and the bacteria are not harmful intrinsically. Conventional challenges of vaccine using lactic acid bacteria using DNA recombinant technique have safety concerns in wide applications such as oral vaccine. In our chemical biology approach to lactic acid bacterial vaccine, wide applications are expected because the epitopedisplaying live bacteria are the same bacteria without genetic modification intrinsically as the original bacteria.

\section{B. Biosynthetic Pathway of Bacterial Cell Wall and Chemical Synthesis of the Cell-Wall Precursors}

The biosynthetic pathway of bacterial cell wall is shown in Fig. 3. It begins from UDP-GlcNAc. The UDPGlcNAc is converted to muramic acid, then, a pentapeptide is formed on the carboxyl group of the muramic acid. The compound, UDP- $N$-Acetylmuramylpentapeptide, is called Park Nucleotide. Then, a lipid, such as undecaprenol, is introduced to the compound to form lipid I. Another GlcNAc is attached to form a disaccharide, Lipid II, which forms a polymerization unit of the cell wall. We synthesized muramic acid derivatives (Scheme 1) as the cell-wall precursor derivatives of this
我々は、安全な生菌 (乳酸菌など) の表層に抗原の一部を 提示さることができれば「疑似生ワクチン」として効率的な粘 膜ワクチンとなりうると考えている。生きた乳酸菌は、腸管か ら効率的に粘膜免疫誘導組織に取り込まれるため、表層の抗原 由来の免疫反応を誘導でき、しかも安全である。乳酸菌を用い たワクチンという試みは国内でも行われているが、遺伝子を改 変するなどのアプローチが中心であり、経口投与という視点で 問題があった。我々のケミカルバイオロジー的な手法では、生 きた菌そのものは遺伝子改変などをしていない安全な菌そのま まであり、経ロワクチンへの応用が期待できる。

\section{B. バクテリア細胞壁の生合成経路と前駆体の化学合成}

バクテリア細胞壁は図 3 に示すような経路で生合成されて いる。UDP- $N$ - アセチルグルコサミンから UDP- $N$ - アセチルム ラミン酸を経て、その後、ムラミン酸のカルボン酸部位にペ プチドが伸長してパークヌクレオチドと呼ばれるUDP- $N$-アセ チルムラミルペンタペプチドとなる。次に脂質（ウンデカプレ ノール) と結合して Lipid I となりここに GlcNAcが結合して Lipid II という 2 糖のユニットができ、細胞壁の糖鎖になって いく。この経路における細胞壁前駆体の誘導体として、ムラ ミン酸誘導体を合成した $($ スキーム 1$)$ UUDP- $N$-アセチルムラ ミルペンタペプチド誘導体 (1おおび 2) は Hitchcockらの方法 (21)を参考にして合成した。

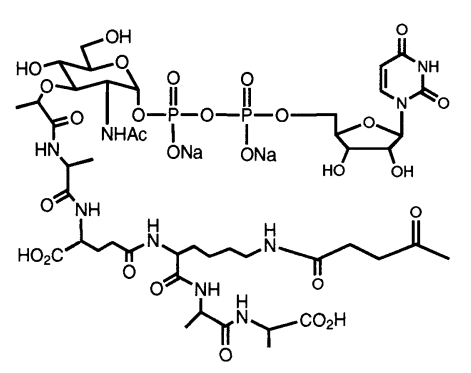

1

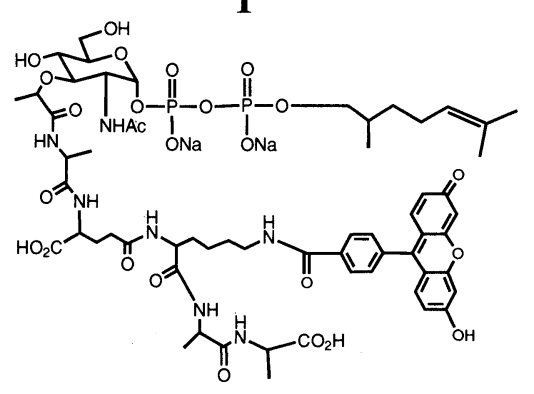

3

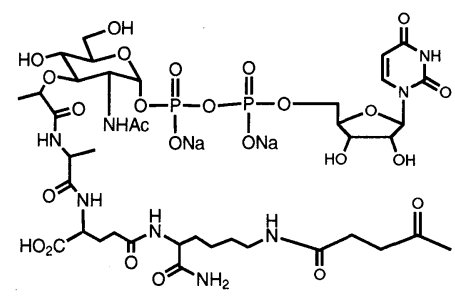

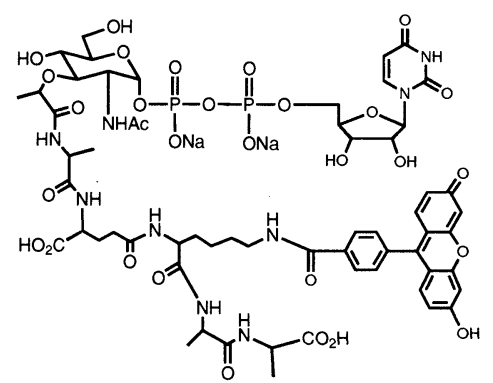

2

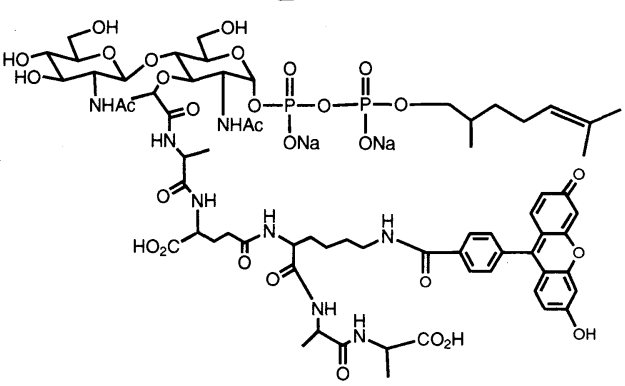

4

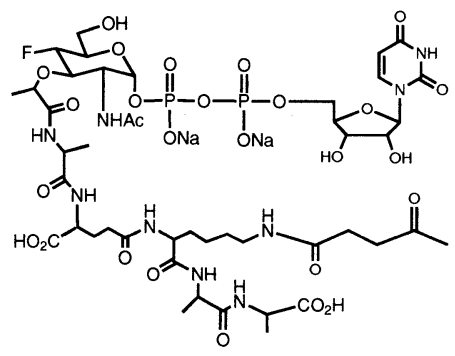

Scheme 1. 

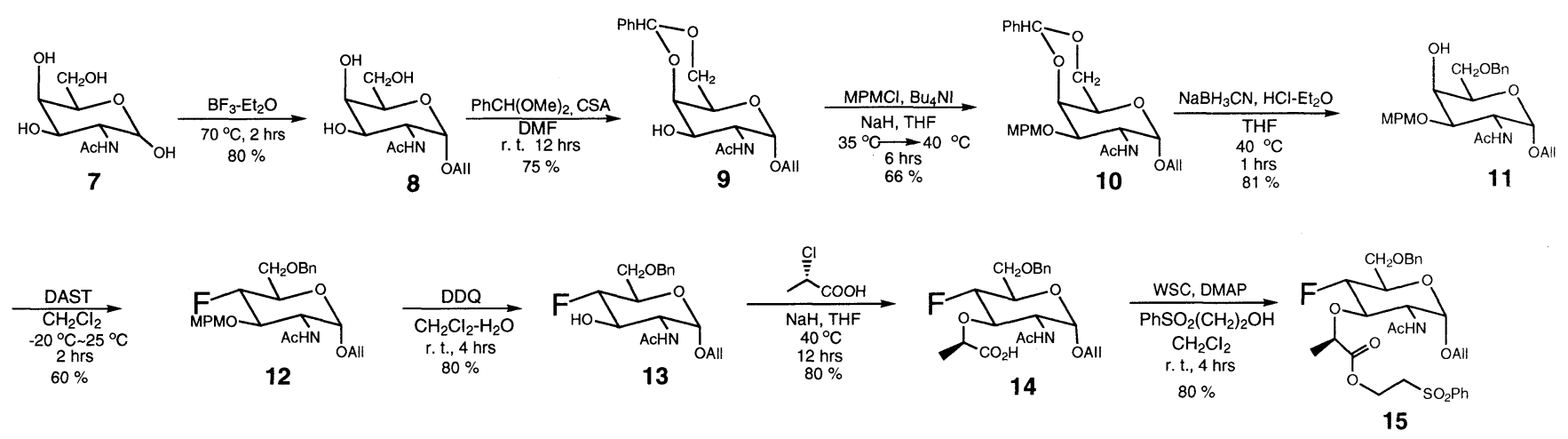

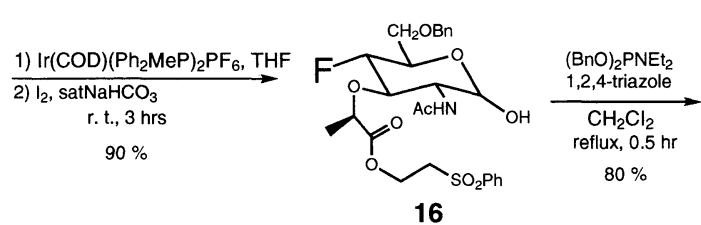

16

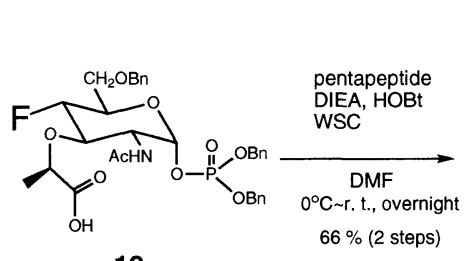

19

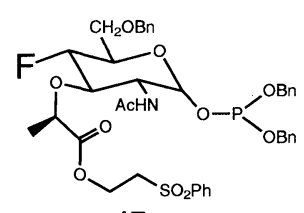

17

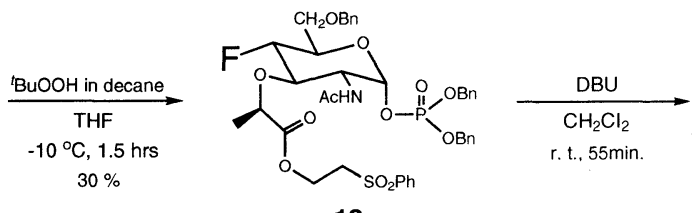

18
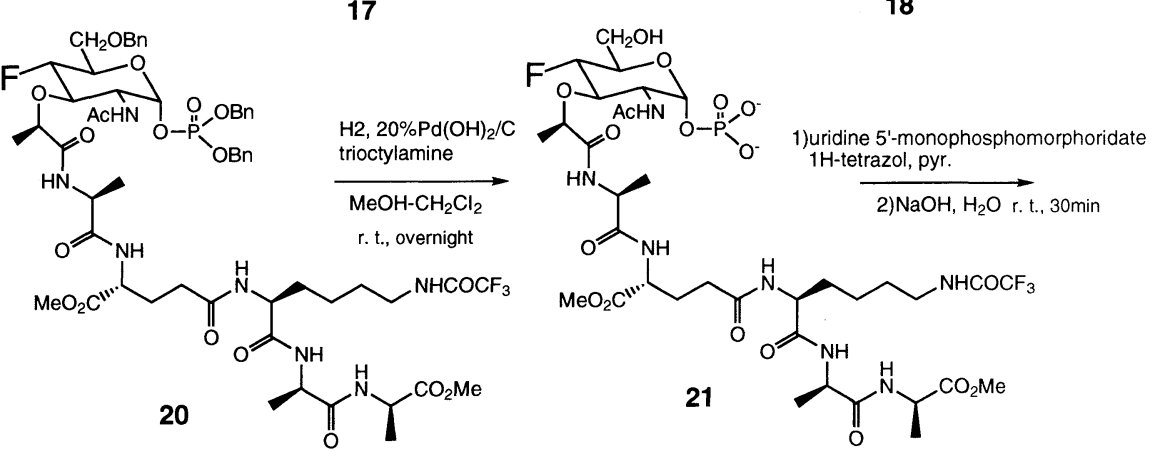

Scheme 2.

biosynthetic route. Compounds 1 and $\mathbf{2}$ were synthesized according to the method described in reference 21 . In lipid I and II, undecaprelyl, which occurs naturally in the lipids, was substituted with a shorter lipid, citronellyl, in consideration of the easy transfer into bacteria. When these precursors are incorporated into the cell wall, fluorophor and ketone moieties are expected to be displayed on the bacterial surface. The synthetic route of 6, 4-fluorinated UDP-MurNAc pentapeptide, is shown in Scheme 2. The key intermediate $\mathbf{1 2}$ was obtained by the fluorination reaction using (diethylamino)sulfur trifluoride (DAST) in $60 \%$ yield. The $p$-methoxyphenylmethyl (MPM) group of $\mathbf{1 2}$ was removed to afford the intermediate 13, which was reacted with $(S)-(-)-2$-chloropropionic acid to give the compound 14. Then, according to the similar route to the UDP-MurNAc pentapeptide, 6 was synthesised. All compounds were identified by NMR and MS after purification.

\section{Incorporation of Synthesized Precursors into Bacterial Cell Wall}

The synthesized precursors were tested for surface display of bacterial cell wall. Lactic acid bacteria ( $L$. Plantarum JCM 1149) were grown in a Lactobacilli MRS broth containing one of the precursors for $15 \mathrm{~h}$. Then
Lipid I 及び lipid II の脂質部位は本来、ウンデカプレノイ ル基であるが、一般的に分子量が大きい（1300～1500 以上の ) 化合物はバクテリア内部には入りにくいと言われていること を考慮して、より低分子量のシトロネロール基で置換した前 駆体 (3 および4)を合成した。これらの前駆体がバクテリア細 胞壁に取り込まれれば、蛍光剤や、レブリン酸のケトン基が バクテリア表層に提示される。UDP- $N$ - アセチルムラミン酸誘 導体 6 は、4 位ヒドロキシル基がフッ素に置換されているが、 この合成ルートはスキーム 2 に示した。鍵となる反応は 11 に フッ素を導入するステップで、DASTを用いて 12 を $60 \%$ \% 収率で得た。3位のヒドロキシル基を選択的に脱保護した後に、 クロロプロピオン酸と反応させ $\mathbf{1 4}$ を得た。ここからは先は基 本的に、UDP-MurNAcペンタペプチドの合成スキームに従っ て進み、最終目的物 6 を得た。最終生成物は HPLC 精製の後、 NMR、MALDI-TOF MS などで同定している。

\section{C. 合成前駆体の細胞壁への取り込み}

合成した前駆体誘導体のバクテリア細胞壁への取り込み を調べた。乳酸菌を合成した前駆体誘導体を $5 \mu \mathrm{M}$ 含む培養液 で 15 時間培養した。乳酸菌は遠心分離によって回収し、そこ にヒドラジド基を持つ蛍光剤を加えてケトン基と反応させた のち、洗浄する。細胞壁への取り込みの確認は、2つの方法 ( 細 胞壁画分の蛍光強度測定およびバクテリアの蛍光顕微鏡観察) 

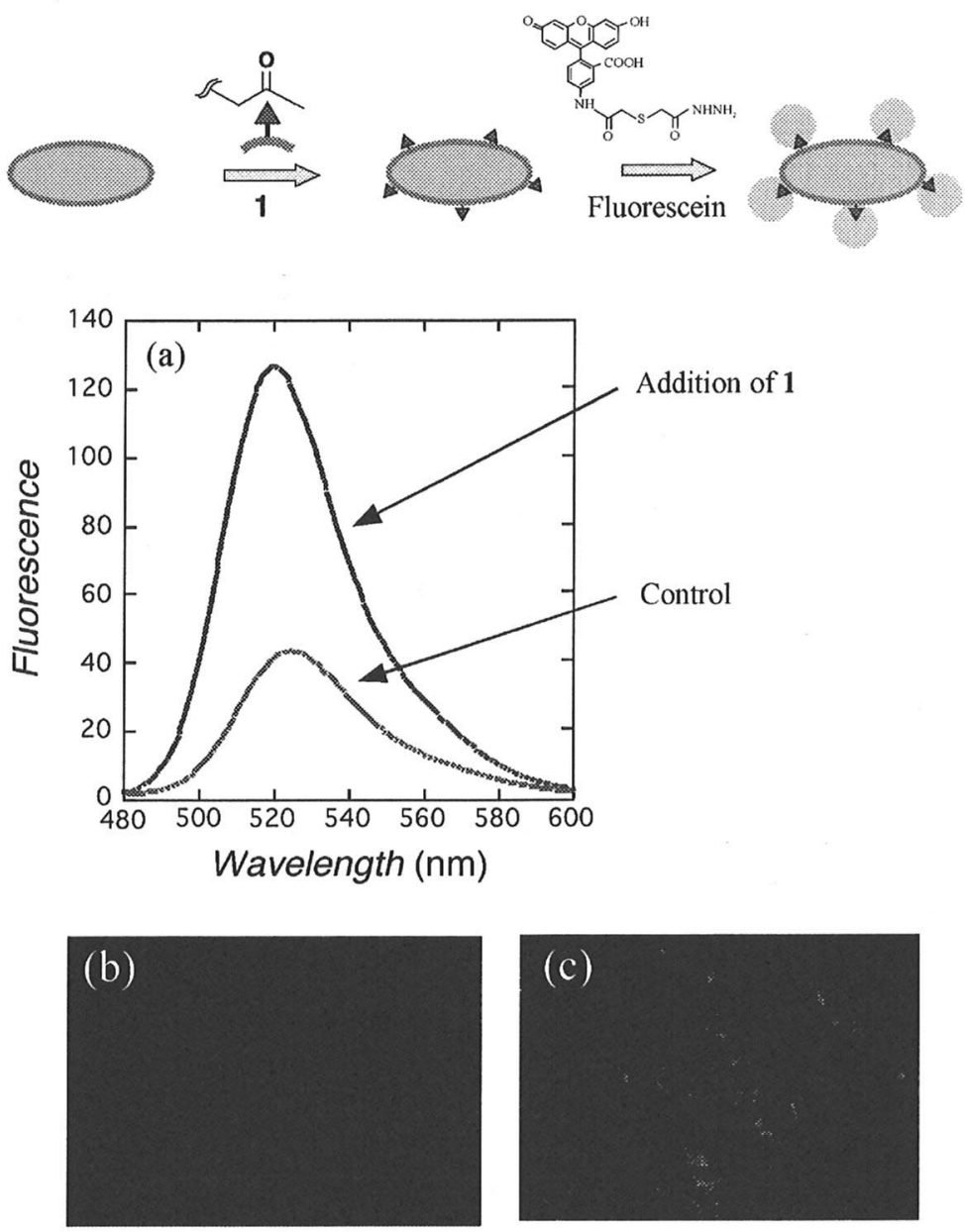

Fig. 4. Fluorescence of lactic acid bacteria after treatment with hydrazine-fluorescent dye. (a) Fluorescence of the extracted cell-wall fractions. Fluorescent images of lactic acid bacteria (b) incubated without $\mathbf{1}$ (c) incubated with $\mathbf{1}$.

the bacteria were collected by centrifugation and added to a solution of hydrazine-attached fluorescent dye and washed. The incorporation was checked by two methods: fluorescence intensity measurement of the cell wall fractions and fluorescent microscopic observation. Fig. 4a shows the fluorescent intensity of cell-wall fraction in the case of using UDP-MurNAc pentapeptide derivative $\mathbf{1}$ as a precursor. The fluorescent intensity of the bacteria incubated with 1 was stronger than the bacteria incubated without 1 , showing that the compound $\mathbf{1}$ was incorporated into the cell wall of the lactic acid bacteria. The surface display was confirmed by microscopic observation. Compound $\mathbf{2}$ was also incorporated into the cell wall, while UDP-MurNAc tripeptide derivative 5, lipid 1 and II derivatives $(3,4)$ were not incorporated into the cell wall. The tripeptide might not be long enough for the incorporation. For the lipid I and II derivatives, the substrate acceptability of MurG enzyme, which works at the transformation from lipid I to lipid II, was investigated by C.-H. Wong et al. (22); MurG accepted some derivatives of lipid moieties, but citronellyl derivative was not a good
により行った。添加する化合物としてUDP-MurNAcペンタペ プチド誘導体 1 を用いた場合の蛍光強度を図 4 に示す。表面 修飾していない乳酸菌 ( 化合物 1 を含まない培養液で培養し た)の場合に比ベ、ケトン基を提示させた乳酸菌を用いた場合 は強い蛍光を示している。これは 1 が乳酸菌にとりこまれ細 胞壁を形成していることを示している。また、この表面修飾 は、細胞壁画分の抽出ではなくバクテリアそのものの蛍光顕 微鏡観察によっても確認できた。フルオレセインを有する前 駆体 2 に関しても同様に取り込みが確認された。一方、UDPMurNAcトリペプチド誘導体 5、Lipid I 及び lipid II 誘導体 $(3 、 4)$ は細胞壁に取り込まれなかった。すなわち、短いトリペプチ ドでは生合成の酵素群に認識されるには十分ではないことが わかった。近年、C.-H. Wong らは lipid I から lipid II を合成す る酵素である MurGの基質選択性について詳細に調べている (22)。MurG は比較的脂質部分の基質認識性は緩いようである が、シトロネロールで置換した lipid I 誘導体は MurG にとって 
substrate. Therefore, the citronellyl moiety of $\mathbf{3}$ and $\mathbf{4}$ should be improved for effective incorporation.

\section{Adhesion Control of Lactic Acid Bacteria by Displaying Oligosaccharides on the ConA-Immobilized Film}

Adhesion behavior of oligosaccharide-displaying bacteria on lectin films was studied. Lactic acid bacteria are gram-positive bacteria that have a thick cell-wall layer at the bacterial surface, enabling the effective display of added molecules. First, the ketone group-displaying bacteria were prepared by growing bacteria in the presence of $\mathbf{1}$ as described above. After the collection of the bacteria by centrifugation, the bacteria were resuspended in a PBS buffer. Since the aminooxyl group reacts with the ketone group to generate the stable oxime bond, the mannopentaose derivative that contains the aminooxyl group can be covalently bound to the ketone-displaying bacteria. The modulation of the bacterial adhesion by cell-wall engineering was tested using the Con A (mannose-binding protein) immobilized surface. Binding of the bacteria was confirmed by microscopic observation (Fig. 5). A suspension of engineered bacteria was mounted on the Con A-immobilized glass plate and washed with PBS buffer. The mannose-displaying bacteria bound more readily to the Con A-immobilized substrate than did natural bacteria, indicating that bacterial adhesion can be manipulated by surface display. These data were also supported by the binding assay using surface plasmon resonance (SPR) spectrometer.
よい基質ではないことを報告している。従って脂質部分の構 造も細胞壁への取り込みには重要であることがわかった。

\section{D. 乳酸菌への糖鎖提示によるレクチン基板への接着性付加}

生きた乳酸菌の表面にオリゴ糖鎖を導入して乳酸菌の接 着性能のコントロールを試みた(18)。乳酸菌は、厚い細胞壁 を持ち外膜がないグラム陽性菌であり、効果的な糖鎖提示が 期待できる。まずケトン基を提示した乳酸菌に対してオキシ ルアミノ基を導入したマンノペンタオース誘導体を結合させ た。糖鎖部位としてマンノペンタオース誘導体を用い、コン カナバリン A (Con A) との相互作用変化を調べた。

図 5 にCon A 固定化基板に対する乳酸菌の吸着を顕微鏡 観察した写真を示した。スライドグラスにCon A を固定化し， 乳酸菌を吸着させ (10 分)、PBS バッファーで洗浄したのち観 察した。乳酸菌にマンノースを提示させると、Con A 基板によ く吸着するようになっていることが観察された。表面修飾バ クテリアのレクチン基板に対する接着挙動の変化は、表面プ ラズモン共鳴法(SPR)によっても確認できた。このようにして、 生きたバクテリアの表面の吸着性能を変化させることが可能 になった。これは腸管での糖鎖認識を利用したバクテリアの 接着制御を現実のものとする可能性を示している。

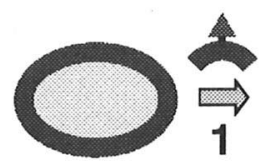

Native lactic acid bacteria
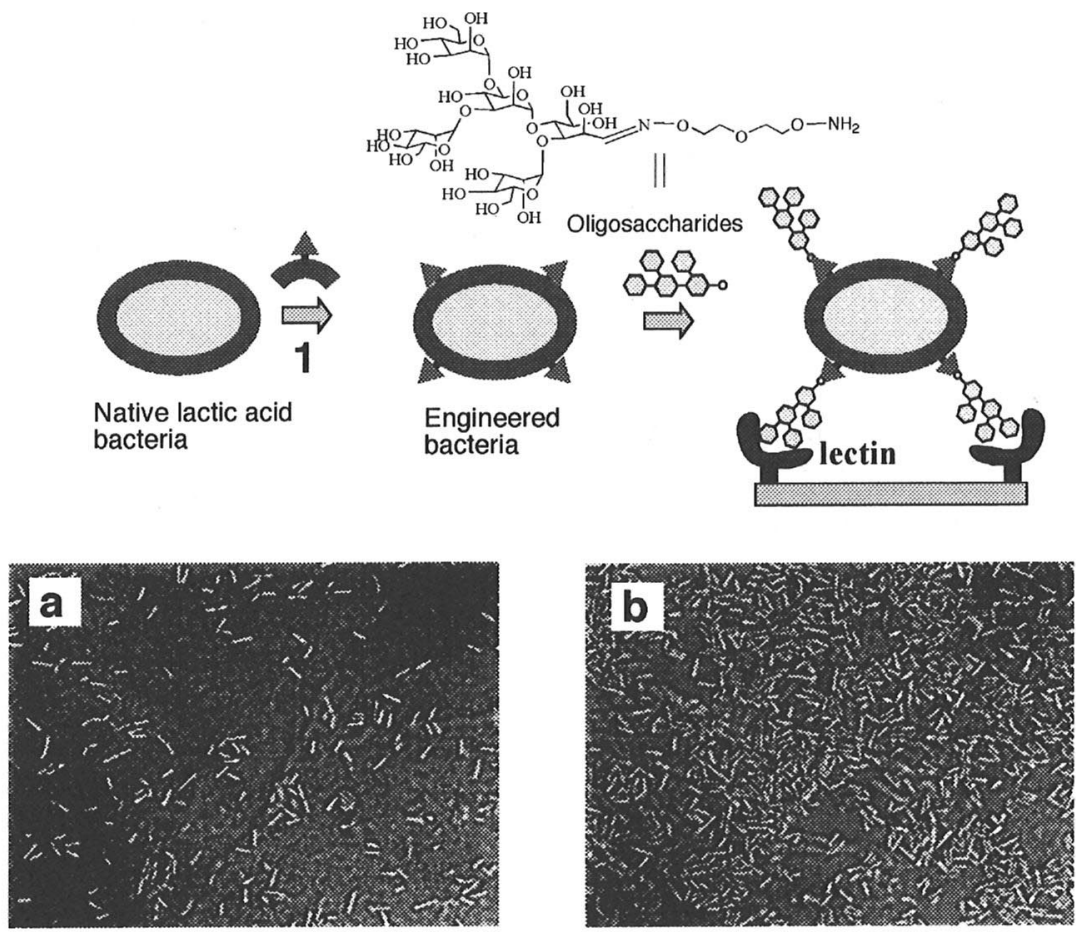

Fig. 5. Binding of (a) natural bacteria and (b) mannosedisplaying bacteria onto a ConA-immobilized substrate. 


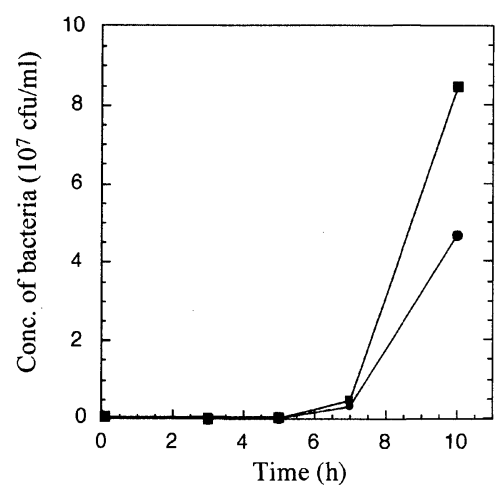

Fig. 6. Changes in bacterial prolification in the presence of compound 6 (closed square) and without 6 (closed circle).

\section{E. Inhibition of Bacterial Growth by Fluorinated Park Nucleotide Derivative}

4-Fluorinated UDP MurNAc pentapeptide 6 was synthesized as a tool for the detection of incorporation via biosynthetic pathway (19). Because 6 cannot be transformed to lipid II (Fig. 3), it is expected to have an inhibitory effect on bacterial growth. It will help to clarify whether the artificial precursors added into the growth media are actually transferred into bacteria.

Lactic acid bacteria (L.plantarum JCM1149) were incubated in a growth medium (BRS broth) containing 6 (0.01 $\mathrm{mg} / \mathrm{ml}, 8.7 \mu \mathrm{M}$ ) under anaerobic conditions at $37^{\circ} \mathrm{C}$. The time courses of the growth of the bacteria with or without 6 are shown in Fig. 6. In the presence of $\mathbf{6}$, the bacterial growth was slower than that in the absence of $\mathbf{6}$. The slower growth may be due to the inhibition of bacterial cell wall biosynthesis by 6 . It suggests that the added compounds such as UDP-MurNAc pentapeptide derivatives were transferred into bacteria and then incorporated in the cell wall.

\section{F. Summary}

This mini-review describes our recent study on bacterial cell-wall engineering. This method is based on the metabolic incorporation of synthetic non-natural precursors into cell wall. Unlike previous methods for cell-surface engineering, our method did not need genetic alteration. We are now in progress to improve precursors to enhance the incorporation efficiencies into bacteria. Utilization of various properties of bacteria, such as probiotics and bioreactors, will be applicable to a wide range of technologies. The artificial modification of bacterial surface will be a versatile technique applied to industries besides mucosal vaccine development referred to in this review.

\section{Acknowledgment}

I would like to thank Prof. S.-I. Nishimura and Dr. K. Niikura for very helpful discussions, to Prof. F. Tomita
E. フッ素化パークヌクレオチド誘導体による増殖阻害

UDP-MurNAcペンタペプチドが乳酸菌内にはいってから 細胞壁へとりこまれているかどうかを調べる手がかりとして、 4 位のヒドロキシル基をフッ素に变えた誘導体 (フッ素化パー クヌクレオチド) 6 を合成した(19)。化合物 6 は原理的には Lipid II に変換されないため (図 3) 細胞壁合成を阻害すること で細胞増殖に影響を与えると思われる。この影響を調べるこ とで添加した今までの前駆体が本当に細胞壁の生合成に関与 しているのかどうかを推察することができる。菌株には、テ クトバシルス属の L. plantarum JCM1149を用いた。この細菌 をフッ素化パークヌクレオチド 6 を $0.01 \mathrm{mg} / \mathrm{ml}(8.7 \mu \mathrm{M})$ で含 む培養液中で嫌気下 $37^{\circ} \mathrm{C} て ゙$ 培養した。コントロールとして、6 を含まない培養液で培養した。各時間での細菌の個体数を算 出した結果、化合物 6 を含む培地では、含まない培地にくら へ、増殖率が低下することがわかった（図 6)。これはフッ素 化パークヌクレオチドが細胞壁生合成経路に取り込まれ、実 際に生合成経路を阻害していることを示している。この結果 は、UDP-MurNAcペンタペプチド誘導体など外から加えた化 合物がバクテリア内部に入り、細胞壁の生合成経路に影響を 与えていることを示唆している。

\section{F. 結 論}

このミニレビューでは私たちが最近進めているバクテリ ア表層を覆っている細胞壁を足場にしたバクテリア細胞表層 工学について紹介した。この方法は、今までの遺伝子工学的 な手法と異なり、細胞壁の前駆体を化学的に細工し、それを バクテリアの増殖時に添加するという今までにない技術であ る。現在は、ここに紹介した前駆体の他にさらに取り迟み効 率の良いものを開発中であり、近々論文として公開できる予 定である。プロバイオティクスやバイオリアクターなどバク テリアのもつ特殊な機能を利用する技術応用は今後多岐にわ たる分野でますます必要とされるであろう。バクテリアの表 層に自由な分子を提示できる技術は、まずは粘膜ワクチンと しての応用を中心に進めているが、今後医療関連以外でも多 様な応用につながって行くであろう。

\section{謝 辞}

本研究は北海道大学理学研究科 西村紳一郎教授の御指 導のもと進められたものであります。また数多くの乳酸菌株 を提供していただきました北海道大学農学部 富田房男名誉 
(Hokkaido University) for the kind gift of the lactic acid bacteria strains. The research in this review was partly supported by a grant for the "Glycocluster Project" from NEDO, a Grant-in-Aid for Young Scientists from the Ministry of Education, Culture, Sports, Science and Technology, the Association for the Progress of New Chemistry, and the Naito Foundation.
教授に感謝申し上げます。本研究は科研費補助金及び新化学 発展協会研究奖励金・内藤記念科学奨励金の支援を受けてい ます。

\section{References}

1. Murai, T., Yoshino, T., Ueda, M., Haranoya, I., Ashikari, T., Yoshizumi, H., and Tanaka, A. (1998) J. Ferment. Bioeng. 86, 569-572

2. Kainuma, M., Ishida, N., Yoko-o, T., Yoshioka, S., Takeuchi, M., Kawakita, M., and Jigami, Y. (1999) Glycobiology 9, 133-141

3. Boder, E.T., and Wittrup, K.D. (1998) Nat. Biotechnol. 86, 569-572

4. Georgiou, G., Stathopoulos, C., Daugherty, P.S., Nayak, A.R., Iverson, B. L., and Curtiss III, R. (1997) Nat. Biotechnol. 15, 29-34

5. Charbit, A., Molla, A., Saurin, W., and Hofnung, M. (1998) Gene 70, 181-189

6. Link, A.J., and Tirrell, D.A. (2003) J. Am. Chem. Soc. 125, 11164-11165

7. Mahal, L. K., Yarema, K. J., and Bertozzi, C. R. (1997) Science 276, 1125-1128

8. Hang, H. C., and Bertozzi, C. R. (2001) J. Am. Chem. Soc. 123, 1242-1243

9. Jacobs, C. L., Goon, S., Yarema, K. J., Hinderlich, S., Hang, H. C., Chai, D. H., and Bertozzi, C. R. (2001) Biochemistry 40, 12864-12874

10. Yarema, K. J., Goon, S., and Bertozzi, C.R. (2001) Nature Biotech. 19, 553-558

11. Yarema, K.J., Mahal, L.K., Bruehl, R.E., Rodriguez, E.C., and Bertozzi, C.R. (2001) J. Biol. Chem. 273, 31168-31179

12. Yarema, K.J., and Bertozzi, C.R. (1998) Curr. Opin. Chem. Biol. 2, 49-61

13. Saxon, E., and Bertozzi, C.R. (2000) Science, 287, 2007-2010

14. Vocadlo, D.J., Hang, H.C., Kim, E.-J., Hanover, J.A., and Bertozzi, C.R. (2003) Proc. Nat. Acad. Sci. USA 100, $9116-9121$

15. Hang, H. C., Yu, C., Kato, D.L., and Bertozzi, C.R. (2003) Proc. Nat. Acad. Sci. USA 100, 14846-14851

16. Sadamoto, R., Niikura, K., Sears, P.S., Liu, H., Wong, C.-H., Suksomcheep, A., Tomita, F., Monde, K., and Nishimura, S.-I. (2002) J. Am. Chem. Soc. 124, 9018-9019

17. Sadamoto, R., Niikura, K., Monde, K., and Nishimura, S.-I. (2003) Methods in Enzymology 362, 273-286

18. Sadamoto, R., Niikura, K., Ueda, T., Monde, K., Fukuhara, N., and Nishimura, S.-I. (2004) J. Am. Chem. Soc. 126, $3755-3761$

19. Ueda, T., Feng, F., Sadamoto, R., Niikura, K., Monde, K., and Nishimura, S.-I. (2004) Org. Lett. 6, 1753-1756

20. Sadamoto, R. (2004) ポリマーフロンティア 21 シリーズ 23,バイオロジクス, 69-91

21. Hitchcock, S.A., Eid, C.N., Aikins, J.A., Zia-Ebrahimi, M., and Blaszczak, L.C. (1998) J. Am. Chem. Soc. 120, $1916-1917$

22. Liu, H., Ritter, T.K., Sadamoto, R., Sears, P.S., Wu, M., and Wong, C.-H. (2003) Chem. Bio. Chem., 603-609

Received on March 8, 2005, accepted on March 31, 2005

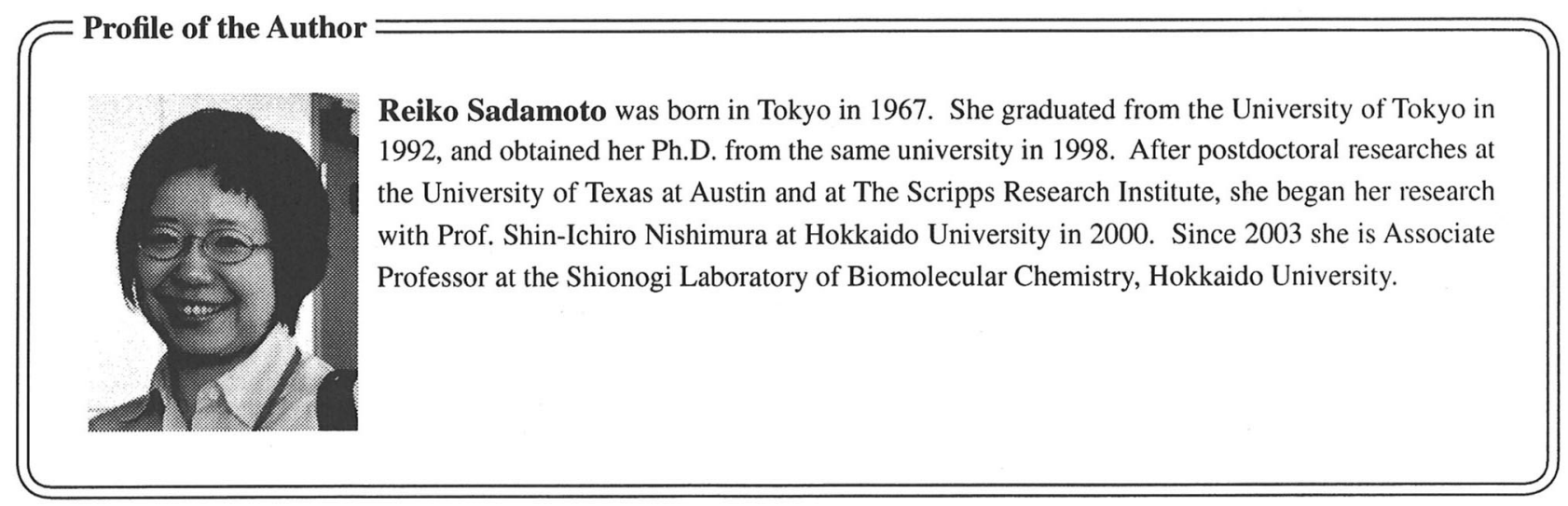

